\title{
Peranan Guru Pendidikan Agama Islam dalam Penanaman Nilai-Nilai Karakter Siswa SMA Negeri 2 Sungai Keruh Musi Banyuasin
}

\author{
Gita Arlia \\ Sekolah Menegah Atas Muhammadiyah 3 Jirak Musi Banyuasin \\ Email: arliagita8@gmail.com
}

\begin{abstract}
Abstrak: Penelitian ini bertujuan untuk mengetahui peranan guru pendidikan agama Islam dalam menanamkan karakter siswa di SMA 02 Sungai keruh. Penelitian ini merupakan penelitian kualitatif dengan jenis deskriptif. Subjek penelitian ini adalah guru PAI SMA 02 Sungai Keruh. Pendekatan yang digunakan dengan pendekatan fenomenologi, Teknik pengumpulan data yang digunakan adalah observasi, wawancara, dan dokumentasi. Instrumen utama adalah peneliti dengan menggunakan alat bantu berupa pedoman observasi, wawancara, dan dokumentasi. Dengan analisis data yang bersifat deskriptif analitik untuk mendapatkan data yang mendalam yaitu suatu data mengandung makna. Berdasarkan hasil temuan melalui pengolahan data observasi, wawancara, dokumentasi serta hasil pembahasan maka dapat disimpulkan bahwa peranan guru PAI dalam menanamkan nilai nilai karakter siswa di SMAN 02 Sungai keruh terlaksana dengan cukup efektif. Nilai karakter yang selalu ingin ditimbul pada diri siswa adalah karakter religius, jujur, mandiri, disiplin, rasa ingin tahu, toleransi dan tanggung jawab. Secara keseluruhan guru telah menanamkan pendidikan karakter kepada siswanya baik itu guru sebagai pengajar, pendidik, pembimbing, penasehat pelatih dan pengevaluasi. Sedangkan karakter yang terbentuk pada diri siswa masih harus terus dipantau perkembangannya dikarenakan siswa masih terpengaruh oleh lingkungan diluar sekolah dan siswa masih suka menghiraukan perintah atau arahan yang diberikan guru saat kegiatan belajar mengajar berlangsung.
\end{abstract}

Kata Kunci: Guru PAI, Penanaman Nilai Karakter.

\begin{abstract}
This study aims at finding out the role of Islamic religion teachers in instilling the character of students at SMAN 2 Sungai Keruh. This research was qualitative descriptive research. The subjects of this study were Islamic Religion teachers of SMAN 2 Sungai Keruh. The approach used was the phenomenological approach. Data collection techniques used were observation, interviews, and documentation. The main instrument was the researcher herself using tools such as observation, interviews, and documentation guidelines. In analyzing the data gained, the researcher used descriptive analytic method to get in-depth data which contained meaning. Based on the findings through the processing of observational data, interviews, documentation and the results of the discussion, it could be concluded that Islamic Religion teachers played effective roles in instilling the character values to students at SMAN 2 Sungai Keruh. Character values that were constantly instilled to students were the characters of religious, honest, independent, disciplined, curious, tolerant and responsible. Overall, the teachers had instilled character education to their students not only as teachers, but also as instructors, educators, mentors, coach advisers and evaluators. While, the characters instilled to students were still needed to be monitored progressively because the students were still affected by the environment outside of school and they still often ignored the instructions or directions given by the teachers when teaching and learning took place.
\end{abstract}

Key Words: Islamic Religion Teacher, Character Value Instillation

\section{Pendahuluan.}

Penelitian ini bermula dari maraknya problem kemerosotan moral yang akhirakhir ini menjangkit sebagian generasi muda. Gejala kemerosotan moral antara lain diindikasikan dengan merebaknya kasus penyalahgunaan narkoba, pergaulan bebas, kriminalitas kekerasan dan aneka perilaku kurang terpuji lainnya. Dilain pihak, tidak sedikit dari generasi muda yang gagal menampilkan akhlak terpuji (akhlakmahmudah) sesuai harapan orang tua. Kesopanan, sifat-sifat ramah, tenggangrasa, rendah hati, suka 
menolong, solidaritas sosial dan sebagainya yang merupakan jati diri bangsa berabadabad seolah-olah kurang begitu melekat secara kuat dalam diri mereka.

Melihat hal tersebut merupakan tanggung jawab para orang tua, pendidik, masyarakat bahkan bangsa dan negara dalam menjaga anak-anaknya yang menjadi generasi penerus bangsa, karena mereka sebagai pendidik utama transfer of culture sehingga jati diri bangsa akan tetap terjaga. UU Nomor 14 Tahun 2005 tentang Sistem Pendidikan Nasional (Sisdiknas) Pasal 3 menyatakan bahwa pendidikan nasional berfungsi mengembangkan kemampuan dan membentuk watak serta peradaban bangsa yang bermanfaat dalam rangka mencerdaskan kehidupan bangsa, bertujuan untuk berkembangnya potensi siswa agar menjadi manusia yang beriman dan bertakwa kepada Tuhan Yang Maha Esa, berakhlak mulia, sehat, berilmu, cakap, kreatif, mandiri, dan menjadi warga negara yang demokratis serta bertanggung jawab.

Undang-undang tersebut sudah jelas dikatakan bahwa pendidikan di Indonesia berfungsi mengembangkan kemampuan dan membentuk watak serta peradaban bangsa dan beberapa point-point yang telah disebutkan. Hal tersebut sangat berkaitan dengan pembentukan karakter yang menjadikan peserta didik dapat mengembangkan potensinya yang memberikan manfaat untuk diri sendiri dan orang lain, sebagaimana pembentukan karakter lebih kepada membentuk watak dari peserta didik yang sesuai dengan budaya bangsa. Sehingga karakter khas pada putra bangsa tetap terjaga.

Tentang karakter di sekolah, Pendidikan Agama Islam selalu disalahkan dari sikap para siswa yang sudah mulai melenceng dari apa yang seharusnya karakter itu terbentuk seacara baik. Dengan demikian bagaimana kita membenahi remaja memasuki masa transisi yaitu dari anak menjadi orang dewasa antara usia 14-19 tahun sekitar masa menempuh Sekolah Menengah Atas. Pada masa ini anak tersebut mengalami masa krisis mulai timbul kritik terhadap dirinya sendiri serta lingkungannya. Tetapi terkadang bersifat lebih subjektif, di mana masa ini anak-anak atau remaja selalu merasa gelisah bahkan tidak stabil (dengan ingin memberontak, gemar mengkritik, suka menentang dan lain sebagainya). Masa remaja tersebut diharapkan mereka mampu untuk beradaptasi dengan masyarakat, memiliki tanggung jawab, memperoleh perangkat nilai dan sistem etis sebagai pegangan dan mengembangkan ideologi.

Melihat fenomena pendidikan dan kondisi remaja saat ini maka penanaman nilai-nilai karakter harus dilakukan secara teratur dan terarah agar siswa dapat mengembangkan dan mempraktekkannya dalam kehidupan sehari-hari. Untuk mencapai tujuan tersebut tidak terlepas dari beberapa faktor penunjang yang tersedia dan terlaksana dengan baik, seperti tenaga pengajar dan staf-staf lain dilingkungan sekolah. Disini peranan guru sangatlah penting untuk menanamkan pendidikan karakter pada siswa. Guru sebagai suri tauladan bagi siswa-siswanya dalam memberikan contoh karakter yang baik sehingga bisa mencetak generasi yang baik pula.

Penulis memilih penelitian di SMA Negeri 02 Sungai Keruh sebagai salah satu SMA unggulan di kecamatan sungai keruh, yang berlebel SMA negeri tetapi sering malakukan kegiatan keagamaannya yang tidak jauh beda dengan sekolah SMA yang berlebel Agama dan siswinya kebanyakan memakai kerudung serta yang mempunyai 
visi, misi, dan tujuan yang lebih mengarah kepada pembentukan karakter siswa serta pengembangan ilmu pengetahuan teknologi. Tetapi terdapat beberapa siswa kerap kali menunjukkan perilaku kurang terpuji. Berdasarkan prapenelitian atau observasi awal ke sekolah, secara kondisi geografis SMA Negeri 02 Sungai Keruh terletak di lingkup wilayah kecamatan, sehingga berbagai akses masih mudah untuk dijangkau dan serba instan. Sebagian siswa SMA Negeri 02 Sungai Keruh ada yang kurang disiplin, kurang bertanggung jawab, terlambat, membolos, tertangkap basah oleh guru, misalnya: ada siswa tidak berpuasa Ramadhan.

Kondisi yang tertulis diatas kurang mencerminkan sebagaimana sekolah merupakan tempat mendidik anak untuk menjadi karakter yang baik yang menjadi contoh bagi masyarakat. Upaya dari guru melihat kondisi tersebut memberikan teguran atau hukuman kepada siswa yang bermasalah, sebagian siswa ada yang mengindahkan dari teguran tersebut tetapi masih ada siswa yang kurang mengindahkan dan siswa pun hanya takut kepada beberapa guru saja. Hal seperti itu yang perlu diperhatikan oleh para guru dalam menanamkan nila-nilai karakter siswa kembali melalui pembiasaan. Dari hal tersebut SMA Negeri 02 Sungai Keruh baru memulai menanamkan pendidikan karakter dalam kegiatan belajar mengajar. Demi terwujudnya tujuan pendidikan maka guru sebagai garda terdepan dalam penanaman nilai-nilai karakter siswa harus dapat berperan aktif untuk membentuk karakter siswanya agar dapat terhindar dari kenakalan remaja.

Dengan demikian, penulis dalam penelitiannya mengambil sampel guru Pendidikan Agama Islam di SMA Negeri 02 Sungai Keruh, guru Pendidikan agama Islam lebih diperhati para siswa karena guru Pendidikan Agama Islam menjadi contoh dan tauladan yang baik dan pelajarannya tersebut sudah menjadi kesatuan dalam diri siswa dibuktikan saat peneliti melakukan observasi, siswa lebih antusias mengikuti kegiatan belajar mengajar mata pelajaran tersebut dikarenakan berkaitan dengan yang dilakukan keseharian sehingga siswa lebih mudah mengikuti. Hal yang menarik diteliti adalah sekolah tersebut kegiatan keagamaanya kuat tetapi tidak didukung dengan beberapa sikap siswanya yang kurang berkarakter baik.

\section{Kajian Litelatur}

Sementara Menurut Thomas Lickona dalam Nurul Zuriah (2008:105-108) Peranan pokok guru yaitu mengajar yang mendidik dan mengajar adalah belajar. Beberapa tugas dan peranan guru yang cukup berat dan perlu dilaksanakan dalam mendukung pelaksanaan budi pekerti atau pendidikan karakter di sekolah,diantaranya: Seorang pendidik atau guru haruslah menjadi model, sekaligus menjadi mentor dari siswa dalam mewujudkan nilai-nilai moral pada kehidupan di sekolah, masyarakat sekolah haruslah merupakan masyarakat bermoral, Praktikkan disiplin moral. Moral adalah sesuatu yang restrictive, artinya bukan merupakan sekedar sesuatu yang deskriptif tentang sesuatu yang baik, tetapi sesuatu yang mengarahkan kelakuan dan pikiran seseorang untuk berbuat baik dan lain sebagainya.

Peranan Guru Terhadap Pendidikan Karakter

Menurut Brown dalam Sardiman (2001: 142), mengatakan bahwa "Tugas dan peranan guru antara lain: menguasai dan mengembangkan materi pelajaran, 
merencanakan dan mempersiapkan pelajaran sehari-hari, mengontrol dan mengevaluasi kegiatan siswa"

Terdapat beberapa peran guru dalam pembelajaran yang dikemukakan Mulyasa (2005: 37-64), bahwa fungsi dan peranan guru dalam proses belajar mengajar adalah sebagai berikut:

1. Guru sebagai pendidik

Guru adalah pendidik, yang menjadi tokoh, panutan dan identifikasi bagi para peserta didik dan lingkungannya.

2. Guru sebagai pengajar

3. Guru membantu peserta didik yang sedang berkembang untuk mempelajari sesuatu yang belum diketahuinya, membentuk kompetensi, dan memahami materi standar yang dipelajari.

4. Guru sebagai pembimbing

5. Guru dapat diibaratkan sebagai pembimbing penjalan (journey) yang berdasarkan pengetahuan dan pengalamannya bertanggung jawab atas kelancaran perjalanan itu. Sebagai pembimbing guru merumuskan tujuan secara jelas, menetapkan waktu perjalanan, menetapkan jalan yang harus ditempuh, menggunakan petunjuk perjalanan.

6. Guru sebagai pelatih

Pembelajaran memerlukan latihan keterampilan, berintelektual maupun motorik sehingga menuntut guru untuk bertindak sebagai pelatih.

7. Guru sebagai penasehat

Guru adalah seorang penasehat bagi peserta didik bahkan bagi orang tua, meskipun mereka tidak memiliki latihan khusus sebagai penasehat dan dalam beberapa hal tidak dapat berharap untuk menasehati orang.

Selain peranan kajian pokok peneliti disini ialah penanaman nilai karakter. Penanaman nilai karakter menurut kamus besar bahasa indonesia ialah : Penanaman secara etimologis berasal dari kata tanam yang berarti menabur benih, yang semakin jelas jika mendapatkan awalan pe-dan akhiran- an menjadi "penanaman" yang berarti proses, cara, perbuatan menanam, menanami atau menanamkan.

Mulyana (2004:199) mengemukakan pendidikan nilai sebagai keseluruhan aspek sebagai pengajaran atau bimbingan kepada peserta didik agar menyadari nilai kebenaran, kebaikan, dan keindahan melalui proses pertimbangan nilai yang tepat dan pembiasaan bertindak yang konsisten.

Secara umum karakter diartikan sebagai perilaku yang dilandasi oleh nilai-nilai berdasarkan norma agama, kebudayaan, hukum/ konstitusi, adat istiadat, dan estetika (Abdullah Munir, 2010:2-3). Kementerian Pendidikan Nasional Badan Penelitian dan Pengembangan Pusat Kurikulum (2010:9-10) menyebutkan nilai-nilai untuk pendidikan budaya dan karakter bangsa sebagai berikut: Religius yaitu sikap dan perilaku yang patuh dalam melaksanakan ajaran agama yang dianutnya, toleran terhadap pelaksanaan ibadah agama lain, dan hidup rukun dengan pemeluk agama lain, Jujur yaitu perilaku yang didasarkan pada upaya menjadikan dirinya sebagai orang yang selalu dapat dipercaya dalam perkataan, tindakan, dan pekerjaan, Disiplin yaitu tindakan yang menunjukkan perilaku tertib dan patuh pada berbagai ketentuan dan peraturan dan lain sebagainya.

Berdasarkan jurnal dengan judul peranan guru terhadap pendidikan karakter siswa di kelas V SDN 1 Sileman karangan iman syahid arifudin menyatakan bahwa peranan guru terhadap pendidikan karakter di kelas $v$ sdn 1 sileman, sudah menanamkan 
nilai-nilai karakter dengan cukup efektif. nilai karakter yang selalu ingin ditimbulkan pada diri siswa adalah karakter jujur, disiplin, dan tanggung jawab. secara keseluruhan guru telah menanamkan pendidikan karakter kepada siswanya di kelas baik itu guru sebagai perancang pembelajaran, pengelola pembelajaran, pengarah pembelajaran, evaluator pembelajaran dan konselor pembelajaran dengan cukup baik.

Sementara menurut jurnal dengan judul Pembentukan Karakter Melalui Pendidikan Agama Islam karangan Nur Ainiyah Universitas Negri Semarang menyatakan bahwa pembentukan karakter anak diaplikasikan dengan adanya materi PAI disetiap sekolah dengan demikian Pola pembelajaran terhadap materi PAI diatas sudah saatnya dirubah. Guru yang menjadi ujung tombak keberhasilan sebuah pembelajaran harus menyadari bahwa tanggung jawabnya terhadap keberhasilan pembelajaran PAI tidak hanya pada tataran kognitif saja. Tetapi tidak kalah penting adalah bagaimana memberikan kesadaran kepada siswa bahwa pendidikan agama adalah sebuah kebutuhan sehingga siswa mempunyai kesadaran yang tinggi untuk melaksanakan pengetahuan agama yang diperolehnya dalam kehidupan sehari-hari. Disinilah dibutuhkan kreatifitas guru dalam menya-

mpaikan pembelajaran, dimana pembelajaran PAI seharusnya tidak hanya diajarkan didalam kelas saja, tetapi bagaimana guru dapat memotivasi dan memfasilitasi pembelajaran agama diluar kelas melalui kegiatan-kegiatan yang bersifat keagamaan dan menciptakan lingkungan sekolah yang religius dan tidak

terbatas oleh jam pelajaran saja.

Indikator keberhasilan pendidikan Karakter adalah jika seseorang telah mengetahui sesuatu yang baik (knowing the good)(bersifat kognitif), kemudian mencintai yang baik (loving the good)(bersifat afektif), dan selanjutnya melakukan yang baik (acting the good) (bersifat psikomotorik).

Hasil temuan dalam beberapa jurnal tentang pembentukan karakter pun diungkapkan dari jurnal karangan R Umi Barroh dengan judul Beberapa Konsep Dasar Proses Belajar Mengajar dan Aplikasinya Dalam Pembelajaran Pendidikan Agama Islam dalam jurnal tersebut menjelaskan bahwa pengaplikasian penanaman nilai karakter kepada siswa bisa tercapai dicapai dengan beberapa aspek diantaranya aspek pendekatan mulai dari pendekatan dalam proses belajar mengajar, Konsep pola mengajar seorang Guru PAI pun menjadi sebuah proses pembentukan dan penanaman nilai karakter bagi seorang siswa.

Selain itu dalam jurnal lain karangan Edi Susanto dengan judul Pendidikan Agama Berbasis Multikultural (Upaya Strategis Menghindari Radikalisme) IAIN Sunan Ampel Surabaya menyimpulkan bahwa penanaman karakter pada siswa itu perlu diadakannya pendidikan agama berbasis multikultural. Sebab, dengan adanya pendidikan agama berbasis multikultural membuat para siswa bisa menerapkan sifat toleransi antar agama, budaya, dan bisa menanamkan sikap bhineka tunggal ika yang telah diterapkan.

Dengan melihat peranan dan tugas guru dalam menanamkan nilai-nilai karakter di atas sebuah proses yang dilakukan oleh guru dalam dalam pendidikan untuk menanamkan nilai-nilai dasar/ karakter pada diri seseorang untuk membangun kepribadian orang tersebut, baik itu nilai karakter yang harus ada antara manusia dengan Tuhannya, nilai karakter yang harus ada antarsesama manusia, lingkungan maupun nilai karakter diri pribadi seseorang. 


\section{Metodologi Penelitian}

Jenis penelitian yang dilakukan dalam penelitian ini adalah metode penelitian kualitatif dengan pendekatan studi fenomenologi. Menurut Jhon W.Creawell (2013:4) penelitian kualitatif merupakan metode-metode untuk mengekplorasi dan memahami makna yang oleh sejumlah individu atau kelompok orang dianggap berasal dari masalah sosial atau kemanusiaan. dalam penelitian ini pun peneliti menggunakan pendekatan fenomenologi. Menurut Rochiati Widiatmaja (2007:96) Selama melakukan studi lapangan, peneliti sendiri yang berperan sebagai key instrument (instrumen kunci) dalam pengumpulan data. Peneliti akan menggunakan tiga metode dalam pengumpulan data yaitu:observasi partisipan, wawancara mendalam,dan dokumentasi. pengambilan sampel sumber data dilakukan secara bersifat "pursposive sampling" atau sampel bertujuan, teknik pengumpulan dengan trianggulasi (gabungan), akan digunakan analisis data kualitatif dengan metode deskriptif analisis yaitu prosedur pemecahan masalah yang diteliti dengan menggambarkan dan melukiskan subjek dan objek penelitian (seseorang lembaga, masyarakat, dan lain-lain), dan hasil penelitian kualitatif lebih menekankan makna dari pada generalisasi.

\section{Hasil dan Pembahasan}

Pembahasan ini akan dilakukan penulis dengan merujuk pada hasil temuan yang diperoleh dari lapangan melalui wawancara, observasi dan dokumentasi. Pada uraian ini peneliti akan ungkap dan paparkan mengenai hasil penelitian dengan cara membandingkan atau mengkonfirmasikannya.

Peran Guru PAI Sebagai Pengajar dalam menanamkan nilai-nilai karakter siswa di SMAN Sungai Keruh. Menurut Brown dalam Sardiman (2001: 142), mengatakan bahwa "Tugas dan peranan guru antara lain: menguasai dan mengembangkan materi pelajaran, merencanakan dan mempersiapkan pelajaran seharihari, mengontrol dan mengevaluasi kegiatan siswa".

Teori tersebut telah diterapkan oleh guru PAI sebagai pengajar di SMAN sungai keruh mempersiapkan bahan ajar, media dan RPP dll sebelum melaksanakan kegiatan pembelajaran pendidikan agama Islam di kelas. Maka peranan guru PAI dalam penanaman nilai karakter siswa untuk pengajaran terus dilakukan dalam proses belajar mengajar di kelas. memberikan motivasi kepada siswa serta mampu menciptakan suasana kelas yang kondusif dengan memberikan tugas beberapa siswa yang dianggap melanggar beberapa aturan.

Guru tersebut mampu menanamkan beberapa nilai-nilai karakter kepada siswa yaitu: nilai religius yang ditunjukkan dengan mengucapkan salam dan berdo'a membaca bacaan basmalah sebelum memulai kegiatan pembelajaran di kelas, nilai jujur dan mandiri yang ditunjukkan dengan melarang siswa menyontek saat mengerjakan tugas dan menanyakan alasan keterlambatan siswa masuk kelas, nilai disiplin yang ditunjukkan dengan absensi siswa satu persatu sebelum pelajaran dimulai dan mengingatkan pakaian seragam siswa yang tidak rapi,nilai rasa ingin tahu dengan membuka dialog dan tanya jawab

Peran guru PAI sebagai pendidik. Berdasarkan hasil temuan yang telah dibahas pada pembahasan sebelumnya, diketahui bahwa penanaman nilia-nilai karakter siswa SMA Negeri 02 Sungai Keruh sudah terlihat jelas dalam kesehariannya di sekolah, baik dalam bidang ibadah maupun bidang akhlak. Peranan guru PAI dalam 
mendidik melalui bimbingan ahlak siswanya terlihat melalui kegiatan keagamaan dan sholat berjamaah, Kegiatan tersebut ini diikuti oleh seluruh warga sekolah SMAN 02 Sungai Keruh termasuk siswa, guru dan karyawan sekolah. Kegiatan tersebut dipimpin dan dibimbing oleh salah seorang dari guru PAI secara bergiliran setiap harinya. Kegiatan shalat Dhuhur berjama'ah tersebut diarahkan untuk menanamkan nilai karakter religius dan disiplin kepada siswa agar mereka patuh dalam menjalankan kewajiban ajaran agamanya secara rutin setiap harinya. Kegiatan ini juga melibatkan peran aktif siswa dalam mengumandangkan adzan dan iqamah sebagai wujud untuk memberikan kesempatan kepada mereka agar melatih diri berani tampil di depan temantemannya. Sedangkan dalam bidang akhlak, seperti mengucapkan salam baik bertemu dengan guru ataupun sesama siswa, menghormati dan mematuhi setiap nasehat baik berupa perintah maupun larangan yang diberikan oleh guru, maupun dari sekolah. prilaku yang ditunjukkan oleh siswa SMA Negeri 02 Sungai Keruh tersebut tidak terlepas dari peran guru sebagai pendidik yang tidak mengenal lelah untuk membina dan Menanamkan nilai-nilai karakter pada siswa.

Hal tersebut sesuai dengan teori Mulyasa (2005: 37-64), Guru adalah pendidik, yang menjadi tokoh, panutan dan identifikasi bagi para peserta didik dan lingkungannya.

Agama Islam memerintahkan bahwa guru tidak hanya mengajar saja, melainkan lebih dalam kepada mendidik. Di dalam merefleksikan pembelajaran, seorang guru harus menstransfer dan menanamkan nilai karakter sesuai dengan yang diajarakan agama Islam. Begitu sentralnya peran guru dalam mendidik siswa maka dibutuhkan integritas dan komitmen dari seorang guru, terlebih lagi peran membina karakter siswa sehingga terbentuk karakter yang baik dalam keseharian siswa. Karakter yag tertanamkan dari peranan guru PAI SMAN 02 Sungai Keruh sebagai pendidik yaitu nilai religius, disiplin.

Selanjutnya guru juga sebagai pembimbing, guru dapat diibaratkan sebagai pembimbing penjalan (journey) yang berdasarkan pengetahuan dan pengalamannya bertanggung jawab atas kelancaran perjalanan itu. Sebagai pembimbing guru merumuskan tujuan secara jelas, menetapkan waktu perjalanan, menetapkan jalan yang harus ditempuh, menggunakan petunjuk perjalanan (Mulyasa 2005: 37-64). Berdasarkan dari hasil temuan bahwa Teori tersebut telah diterapkan oleh guru PAI Mengenai kegiatan dan bentuk bimbingan yang dilakukan RW dan MM peranan guru PAI dalam menanamkan nilai karakter dengan cara memberikan nasehat dan memberikan bimbingan untuk kemandirian siswa seperti bekerja sama dengan osis untuk membuka kantin kejujuran di sekolah. Karakter yang tumbuh yaitu nilai karakter kejujuran dan nilai karakter sahabat komunikatif.

Selanjutnya guru dalam pembelajaran memerlukan latihan keterampilan, berintelektual maupun motorik sehingga menuntut guru untuk bertindak sebagai pelatih. (Mulyasa 2005: 37-64). Berdasarkan hasil temuan yang telah dibahas pada pembahasan sebelumnya, diketahui bahwa penanaman nilia-nilai karakter siswa SMA Negeri 02 Sungai Keruh sebagai pelatih terlihat pada kegiatan keseharian siswa disekolah seperti shalat dzuhur berjamaah disekolah, ketaatan dalam menjalankan shalat lima waktu mengandung nilai kejujuran, kedisiplinan dan tanggung jawab. Guru pendidikan agama Islam SMAN 02 Sungai Keruh memberikan buku mentor sebagai pengendali bagi peserta didik dalam menjalankan rukun Islam yang ke dua yaitu shalat. Buku tersebut sebagai bukti ketaatan peserta didik dalam beribadah. 
Melalui buku pengendali tersebut peserta didik dilatih untuk jujur terhadap diri sendiri, Allah dan orang lain. Lewat kedisiplinan peserta didik dalam menjalankan shalat lima waktu dapat melatih peserta didik untuk disiplin dalam segala hal. Pengisian buku mentor atau pengendali sebagai strategi guru pendidikan agama Islam dalam mendidik tanggung jawab pada peserta didik.

Guru adalah seorang penasehat bagi peserta didik bahkan bagi orang tua, meskipun mereka tidak memiliki latihan khusus sebagai penasehat dan dalam beberapa hal tidak dapat berharap untuk menasehati orang. (Mulyasa 2005: 37-64),.

Pada proses pembelajaran guru pendidikan agama Islam memberikan nasihat kepada peserta didik untuk selalu berprilaku baik dan jujur, karena Allah Maha Mengetahui apa yang dilakukan manusia. Guru SMAN 02 Sungai Keruh. yang selalu memberi nasihat untuk selalu berbuat jujur. Selain kejujuran guru pendidikan agama Islam SMA N 02 Sungai Keruh selalu memberikan nasihat agar peserta didik cerdas dalam memilih teman. Peserta didik tingkat SMA tergolong sebagai pribadi dalam fase labil dan perilaku kehidupannya lebih terpengaruh pada lingkungan pergaulan. Pergaulan yang salah akan berpengaruh pada karakter yang dimiliki peserta didik di masa mendatang, sekalipun sudah tidak ada komunikasi dengan temannya, nilai karakter jujur yang tertanamkan kepada siswa pada peranan guru sebagai nasihat.

Peran guru PAI sebagai model dan teladan. Dalam pembahasan temuan sebelumnya, peneliti temukan bahwa peran guru PAI SMK Negeri 02 Sungai Keruh menanamkan nilai-nilai karakter pada siswa salah satunya adalah dengan menjadi model atau teladan. Hal itu dikarenakan dengan menjadi model atau teladan guru akan dapat menanamkan perilaku Islami pada siswa secara maksimal. Siswa secara tidak langsung akan meneladani segala tindak-tanduk yang dilakukan oleh guru, itu merupakan salah satu cara yang efektif dalam meningkatkan nilai karakter siswa. Dengan menjadi model atau teladan, diharapkan tumbuh kesadaran dari siswa untuk berahlak baik.

Sikap keteladanan Guru pendidkan agama Islam SMAN 02 Sungai Keruh memberikan teladan kepada peserta didik diantaranya dengan on time dalam pembelajaran. Guru SMAN 02 Sungai Keruh tidak hanya menyuruh peserta didik agar tepat waktu sampai di sekolah, tetapi juga memberi teladan dengan membiasakan diri untuk tepat waktu dalam setiap kegiatan Peran guru sebagai role model dalam hal ketepatan waktu sudah tercermin dalam keseharian, selalu mengucapkan salam baik bertemu dijalan maupun ketika memulai pembelajaran, pada saat pelajaran akan dimulai guru juga memimpin siswa untuk berdoa, selain itu pada akhir pembelajaran guru selalu memberikan motivasi kepada siswa untuk selalu berperilaku terpuji. Keteladan guru PAI juga terlihat dari kedisiplinan dan tanggung jawab yang diperlihatkan guru pada saat mengajar maupun diluar jam pelajaran. Hal tersebut yang akhirnya secara tidak langsung ditiru oleh siswa dan menjadi budaya yang baik dalam berperilaku.

Sebagai teladan, tentu saja pribadi dan apa yang dilakukan guru akan mendapat sorotan peserta didik serta orang sekitar lingkungannya yang menganggap atau mengakuinya sebagai guru. Sehubungan dengan itu Mulyasa mengungkapkan: ada beberapa hal di bawah ini perlu mendapat perhatian dan bila perlu didiskusikan para guru.

1. Sikap dasar: postur psikologis yang akan nampak dalam masalah- masalah penting, seperti keberhasilan, kegagalan, pembelajaran, kebenaran, hubungan antar manusia, agama, pekerjaan, permaian dan diri. 
2. Bicara dan gaya bicara: pengguanaan bahasa sebagai alat berfikir,Kebiasaan bekerja: gaya yang dipakai oleh seseorang dalam bekerja yang ikut mewarnai kehidupannya.

3. Sikap melalui pengalaman dan kesalahan: pengertian hubungan antara luasnya pengalaman dan nilai serta tidak mungkinnya mengelak dari kesalahan.

4. Pakaian: merupakan perlengkapan pribadi yang amat penting dan menampakkan ekspresi seluruh kepribadian.

5. Hubungan kemanusiaan: diwujudkan dalam semua pergaulan manusia, intelektual, moral, keindahan, terutama bagaimana berperilaku.

6. Proses berfikir: cara yang digunakan oleh pikiran dalam menghadapi dan memecahkan masalah.

7. Keputusan: ketrampilan rasional dan intuitif yang dipergunakan untuk menilai setiap situasi

8. Gaya hidup secara umum: apa yang dipercaya oleh seseorang tentang setiap aspek kehidupan dan tindakan untuk mewujudkan kepercayaan itu (Mulyasa 2008:32)

Sehingga peneliti berkesimpulan setidaknya ada tiga hal yang dilakukan oleh guru PAI untuk memberikan keteladanan bagi siswa dalam menanamkan nilai-nilai karakter siswa di SMAN 02 Sungai Keruh sebagai berikut: Pertama, selalu berusaha membimbing siswa-siswi untuk berperilaku dengan baik, mengingatkan jika mereka melakukan perbuatan yang tidak terpuji. Kedua, selalu berusaha memberikan contoh yang baik bagi siswa agar para siswa memberikan feedback yang baik pula dalam kehidupan sehari-hari. Ketiga, memberikan contoh nyata pada saat kegiatan belajar mengajar seperti selalu mengaucapkan salam, mengajak berdoa bersama, mengingatkan siswa untuk berbuat baik dan sebagainya, maka secara tidak langsung siswa akan meneladani apa yang di contohkan oleh gurunya.

Peran guru PAI sebagai evaluator. Evaluasi atau penilaian merupakan aspek pembelajaran yang paling kompleks, karena melibatkan banyak latar belakang dan hubungan, serta variable lain yang mempunyai arti apabila berhubungan dengan konteks yang hampir tidak mungkin dapat dipisahkan dengan setiap segi penilaian.

Dalam rangka menanamkan nilai karakter siswa di SMA Negeri 02 Sungai Keruh ada beberapa upaya dalam menanamkan nilai-nilai karakter pada siswa yaitu guru melakukan evaluasi secara menyeluruh dengan mengevaluasi aspek afektif, kognitif dan psikomotorik, yaitu dengan sering mengadakan kajian Islam, dan mewajibkan siswanya untuk shalat berjamaah,. Guru PAI juga bekerja sama dengan pembina perpustakaan dengan sering mengadakan kunjungan perpustakaan setiap seminggu sekali, selain itu di setiap kelas guru PAI juga membentuk klub kajian Islam. Dengan langkah tersebut penanaman nilai karakter siswa SMA Negeri 02 Sungai Keruh berjalan dengan baik.

Menurut (Mulyasa 2008:32) mengatakan: Terdapat dua fungsi dalam memerankan perannya sebagai evaluator, yaitu Untuk menentukan keberhasilan siswa dalam mencapai tujuan yang telah ditentukan atau menentukan keberhasilan siswa dalam menyerap materi kurikulum. Untuk menentukan keberhasilan guru dalam melaksanakan seluruh kegiatan yang telah dirancang dan diprogramkan

Sehingga guru PAI tidak hanya sebatas menilai dan mengevaluasi dari sisi akademik saja, akan tetapi lebih luas yaitu mencakup segala aspek termasuk tingkah laku sosial peserta didik. 
Oleh karena itu guru bertanggung jawab untuk mengevaluasi segala aspek yang ada dalam lingkup pendidikan. Tidak hanya aspek kognitif saja, akan tetapi dalam aspek afektif dan psikomotoriknya juga harus berjalan seimbang. Sehingga kompetensi yang diharapkan oleh guru dapat dicapai siswa secara maksimal, maka dari itu evaluasi merupakan komponen yang harus dilaksanakan oleh guru untuk memperbaiki aspek-aspek yang belum maksimal dicapai oleh siswa. Sehingga tujuan guru untuk menanamkan nilai-nilai karakter pada siswa tercapai secara maksimal.

Setiap usaha atau kegiatan yang tidak ada tujuan, maka hasilnya akan sia-sia dan tidak terarah. Bila pendidikan kita pandang suatu proses, maka proses tersebut akan berakhir pada pencapaiannya pada akhir tujuan pendidikan. Tujuan yang hendak dicapai oleh pendidikan pada hakekatnya adalah suatu perwujudan dari nilai-nilai ideal yang dibentuk dalam pribadi manusia yang diinginkan. Nilai-nilai inilah yang nantinya akan mempengaruhi penanaman nilai-nilai karakter manusia sehingga akan berdampak mempengaruhi pada tingkah lakunya.

Namun, menurut identifikasi Mulyana, paling tidak ada empat hambatan utama pembelajaran nilai di sekolah, yaitu (1) masih kukuhnya pengaruh paham behaviorisme dalam system Pendidikan Indonesia sehingga keberhasilan belajar hanya diukur dari atribut- atribut luar dalam bentuk perubahan tingkah laku, (2) kapasitas pendidik dalam mengangkat struktur dasar bahan ajar masih relative rendah, (02), tuntutan zaman yang semakin pragatis, (4), sikap yang kurang menguntungkan bagi pendidikan. Meskipun telah teridentifikasi ada berbagai hambatan pembelajaran nilai di sekolah, namun ada juga beberapa faktor yang mendorong pembelajaran nilai di Sekolah Menengah Atas, yaitu (1) pengalaman pra sekolah, (2) tingkat kecerdasan, (02) kreativitas, (4), motivasi belajar, (5) sikap dan kebiasaan belajar. (Wina Sanjaya, 2011: 31-32)

Dari penjelasan tentang adanya faktor penghambat dan pendorong pembelajaran nilai di sekolah, dapat ditarik kesimpulan bahwa secara garis besar ada dua faktor yang mempengaruhi karakter seseorang.Diantaranya yaitu faktor internal dan faktor eksternal. (Sjarkawi, 2006: 19)

Oleh sebab itu, dalam suatu kegiatan pastilah tidak lepas dari dukungan dan hambatan dalam penanaman nilai-nilai karakter siswa. Faktor pendukung dan faktor penghambat yang dapat mempengaruhi penanaman nilai-nilai karakter siswa yaitu:

1. Faktor Pendukung

a. Motivasi dan Dukungan Orang Tua

Motivasi pola hidup berkarakter tidak hanya diberikan oleh pihak sekolah saja, melainkan juga dari orang tua, karena setelah sampai di rumah, siswa akan dibina langsung oleh orang tua masing-masing dalam berperilaku. Diantara faktor terpenting dalam lingkungan keluarga dalam pembentukan karakter anak adalah pengertian orang tua

Akan kebutuhan kejiwaan anak yang pokok, anatara lain rasa kasih sayang, rasa aman, harga diri, rasa bebas, dan rasa sukses.

Selain perhatian, orang tua juga memberikan teladan yang baik bagi anakanaknya, ketenangan dan kebahagiaan merupakan faktor positif yang terpenting dalam penanaman nilai-nilai karakter anak.

Siswa yang bersekolah di SMA Negeri 02 Sungai Keruh tidak akan merasa nyaman belajar dan termotivasi untuk menaati peraturan di sekolah jika tidak didukung oleh keluarganya. 
Seperti yang telah diungkapkan oleh informan DR, AM, dan FH dalam wawancaranya dengan peneliti. Mereka yang memperoleh dukungan baik materi maupun non materi dari orang tua dan keluarganya berusaha untuk selalu menaati peraturan dan perintah guru serta berusaha untuk menjadi yang terbaik.

Keluarga merupakan satuan sosial yang paling sederhana dalam kehidupan manusia. Anggota-anggotanya terdiri atas ayah, ibu dan anak-anak bagi anak-anak keluarga merupakan lingkungan sosial yang pertama yang dikenalnya.Dengan demikian, kehidupan keluarga menjadi fase sosialisasi awal bagi pembentukan kejiwaan anak.

Perkembangan jiwa keagamaan anak dipengaruhi oleh citra anak terhadap bapaknya (Jalaludin \& Said Usman, 1994: 209). Jika seorang bapak menunjukkan sikap dan tingkah laku yang baik, maka anak akan cenderung mengidentifikasi sikap dan tingkah laku sang bapak pada dirinya. Demikian pula sebaliknya, jika bapak menampilkan sikap buruk juga akan berpengaruh terhadap pembentukan kepribadian anak. Pengaruh kedua orang tua terhadap perkembangan jiwa keagamaan anak dalam pandangan Islam sudah lama disadari.Oleh karena itu, orang tua bertanggung jawab atas perkembangan jiwa keagamaan anak.

Ada semacam rangkaian ketentuan yang dianjurkan kepada orang tua, yaitu mengadzankan telinga bayi yang baru lahir, mengaqiqah, memberi nama yang baik, mengajarkan membaca Al-Quran, membiasakan shalat serta bimbingan lainnya yang sejalan dengan perintah agama. Keluarga dinilai sebagai faktor yang paling dominan dalam meletakkan dasar bagi perkembangan jiwa keagamaan.

Dari penjelasan di atas, dapat disimpulkan bahwa lingkungan keluarga adalah merupakan suatu hal yang sangat berpengaruh sekali terhadap proses pendidikan karakter yang selama ini diterima oleh siswa, dalam arti apabila lingkungan keluarga baik, maka baik pula kepribadian anak, yang mana hal tersebut merupakan alat penunjang dalam penanaman nilai-nilai karakter siswa.

b. Komitmen Bersama

Sangat sulit merubah atau membuat kebiasaan baru pada suatu lembaga tanpa adanya komitmen bersama.Adanya komitmen bersama diawali dengan adanya pengertian, pengetahuan dan keyakinan individu-individu warga sekolah di SMA Negeri 02 Sungai Keruh terhadap tujuan bersama.Bersama- sama membentuk pengarahan, pembinaan, dan pengembangan agar mampu mengembangkan diri, ilmu, tugas-tugas hidupnya, mewujudkan karakter yang mulia dan berperanan aktif dalam membangun kehidupan guna menjalankan tugas dan kewajibannya sebagai seorang pendidik.

c. Fasilitas yang Lengkap

SMAN 02 Sungai Keruh telah berdiri selama 8 tahun dan telah memiliki fasilitas yang lumayan lengkap walaupun masih ada sedikit kekurangan.Fasilitas yang dimaksud adalah sarana dan prasarana yang mendukung yang digunakan sebagaimana mestinya. Diantaranya yaitu:

1) Ruang Kelas sudah digunakan sebaik mungkin yaitu digunakan untuk kegiatan proses belajar mengajar.

2) Mushola sudah digunakan sebaik mungkin yaitu digunakan untuk sholat dhuhur berjamaah dan digunakan untuk praktik tentang beribadah apapun terkait dengan materi pendidikan agama Islam 
3) Buku-buku perpustakaan sudah digunakan sebaik mungkin yaitu digunakan untuk proses pembelajaran, untuk menambah wawasan siswa seperti halnya buku cerita yang mendidik

4) Laboratorium IPA yang biasa digunakan untuk berbagai praktikum proses belajar mengajar yang berhubungan dengan ilmu pengetahuan alam.

5) Lapangan yang sudah digunakan dengan sebaik mungkin yaitu digunakan untuk berbagai macam olahraga dan juga bisa digunakan lomba-lomba antar kelas.

6) Koperasi Sekolah sudah digunakan dengan sebaik mungkin yaitu digunakan untuk menjual berbagai kebutuhan macam-macam alat-alat tulis.

2. Faktor Penghambat:

a. Latar Belakang Siswa

Karena para siswa berangkat dari latar belakang yang berbeda, maka tingkat agama dan keimanannya juga berbeda-beda Lingkungan keluarga merupakan suatu hal yang sangat berpengaruh sekali terhadap proses pembentukan pendidikan karakter anak yang diperoleh di sekolah, dengan kata lain apabila anak berasal dari latar belakang keluarga yang agamis maka akhlak atau karakter anak juga akan baik, akan tetapi lain halnya apabila latar belakang anak buruk maka akhlak atau karakter anak juga akan buruk.

b. Kurang Kesadaran Siswa

Guru Pendidikan Agama Islamdan guru pendidikan agama Islam telah berusaha mencanangkan pembiasaan baik setiap hari, dan memberikan contoh secara rill, akan tetapi masih banyak siswa yang belum sadar untuk melaksanaknnya. Contohnya adalah ketika tiba waktunya sholat Dhuhur berjamaah setelah pelajaran berakhir bagi siswa kelas empat, lima dan enam, para peserta didik senantiasa semangat untuk mengikuti sholat berjamaah tersebut, namun tetap masih ada yang tidak mengikuti sholat berjamaah. Mereka hanya mengikuti doa bersama-sama saja.

Menurut guru pendidikan agama Islam di SMA Negeri 02 Sungai Keruh ini siswa penuh alasan untuk tidak mengikuti sholat dzuhur berjamaah. Ketika peneliti bertanya kepada siswa tentang alasan mereka jarang mengikuti sholat Dhuhur berjamaah adalah sebagai berikut:

1) Informan DR : "malas badan sudah lesu

2) Informan AM: waktunya sangat singkat dan terburu-buru

3) Informan FH : capek dan tidak ada pengakuan yang tegas bagi yang tidak mengikuti sholat dhuhur berjamaah.

Dari penjelasan beberapa siswa Sekolah Menengah Atas di atas, maka peneliti dapat menganalisis, bahwa hal itu terjadi karena ada dua faktor. Diantaranya yaitu:

a. Tingkatan Umur Siswa

Anak usia remaja yang biasanya suka menyangkal atas nasehat yang sudah diterimanya karena merasa bahwa dirinya adalah yang paling benar, banyak berkata dibanding berpikir mendalam sebelum berkata- kata. Sangat berbeda dengan orang dewasa yang lebih bersabar, berkemampuan untuk berpikir dan berusaha keras, berpikir terlebih dahulu sebelum berkata dan bersikap hati-hati dengan maksud tidak merugikan orang di sekitarnaya.

Hal ini terjadi karena perbedaan tingkatan umur seseorang. Orang yang lebih dewasa, dia akan memiliki kematangan kepribadian dalam bertindak, beda dengan 
remaja yang tingkat kematangan kepribadiannya masih labil. Oleh karena itu, watak atau karakter seseorang itu dapat dipengaruhi dengan tingkatan umur yang berbeda.

b. Fitrah (Bawaan) Manusia

Agama mengajarkan bahwa setiap manusia mempunyai kecenderungan (Fitrah) untuk mencintai kebaikan.Namun fitrah ini bersifat potensial atau belum termanifestasikan ketika anak dilahirkan.Setiap anak yang terlahir belum mempunyai pengendalian terhadap dirinya sendiri.Ia belum mampu mengelola-mengelola keinginannya. Oleh sebab itu penanaman dan pembiasaan karakter terhadap anak dapat dilakukan sedini mungkin. (Dokumentasi Sarana dan Prasarana SMA Negeri 02 Sungai Keruh)

c. Lingkungan atau Pergaulan Siswa

Keberhasilan dan ketidakberhasilan pelaksanaan pembelajaran sedikit banyaknya juga dipengaruhi oleh lingkungan sekitar. Jika keberadaan lingkungan sekitar mampu mencerminkan positif bagi proses pembelajaran, maka ia mampu memberikan kontribsi yang baik bagi pelaksanaan pendidikan. Sebaliknya jika kontribusi lingkungan tidak terbukti, tidak relevan dengan proses pembelajaran, jelas akan mempengaruhi kekurangan maksimal proses pendidikan itu sendiri.

Lingkungan pergaulan adalah lingkungan keluarga, lingkungan organisasi, lingkungan kehidupan ekonomi dan lingkungan pergaulan yang bebas. Demikian faktor lingkungan yang dipandang cukup menentukan pematangan watak dan tingkah laku seseorang. (Hamzah Ya'qub, 1993: 18)

Dari data yang diperoleh menunjukkan bahwa lingkungan masyarakat di SMA Negeri 02 Sungai Keruh dengan keadaan masyarakat dengan pergaulan siswanya yang terlalu bebas dengan masyarakat sekitar, di samping suasana masyarakat sekitar dan lokasi yang kurang mendukung karena sekolah terletak di pinggir perkebunan sehingga mudah membuat anak untuk bersembunyi dan kabur dari sekolah. Jadi dapat disimpulkan bahwa faktor lingkungan juga mempengaruhi terhadap penanaman nilainilai karakter siswa.

Dari uraian di atas dapat disimpulkan bahwa lingkungan masyarakat bukan merupakan lingkungan yang mengandung unsur tanggung jawab, melainkan hanya merupakan unsur pengaruh belaka, tapi norma dan tata nilai yang ada terkadang lebih mengikat sifatnya. Bahkan terkadang pengaruhnya lebih besar dan perkembangan jiwa.

Keagamaan baik dalam bentuk positif maupun negatif. Misalnya lingkungan masyarakat yang memiliki tradisi keagamaan yang kuat akan berpengaruh positif bagi perkembangan jiwa keagamaan anak, akan tetapi lingkungan masyarakat yang tradisi keagamaannya kurang, maka akan membawa pengaruh yang negatif terhadap perkembangan jiwa keagamaan anak.

Menurut peneliti, berdasarkan hasil penelitian pada faktor pendukung dan penghambat penanaman nilai-nilai karakter peserta didik jika dikaitkan dengan pendapat Sjarkawi yang sudah dibahas di atas termasuk ke dalam faktor internal dan eksternal. Berikut uraiannya:

a. Faktor Internal yang mendukung peranan guru dalam penanaman nilai-nilai karakter peserta didik adalah motivasi dan dukungan orang tua. Sedangkan yang menghambat adalah latar belakang siswa yang kurang mendukung dan kurangnya kesadaran siswa. 
b. Faktor Eksternal yang mendukung peranan guru dalam penanaman nilai-nilai karakter siswa adalah komitmen bersama dari pendidik dan fasilitas yang mendukung. Sedangkan yang menghambat lingkungan atau pergaulan siswa.

\section{Kesimpulan}

Berdasarkan hasil temuan melalui pengolahan data observasi, wawancara dan telaah dokumentasi Peneliti dapat menyimpulkan bahwasannya peranan guru PAI di SMA 02 Sungai Keruh sebagai pengajar, pendidik, pembimbing, penasehat pelatih dan pengevaluasi dalam menanamkan nilai karakter cukup berperan aktif dalam menanamkan nilai-nilai karakter siswa. Dalam hal ini peranan guru PAI di SMA 02 Sungai Keruh tersebut secara keseluruhan guru telah menanamkan pendidikan karakter kepada siswanya, dari peranan yang ada guru dapat menanamkan nilai religius, jujur, mandiri, disiplin, rasa ingin tahu, toleransi dan tanggung jawab.

Faktor yang mempengaruhi peranan guru Pendidikan Agama Islam dalam menanamkan nilai-nilai karakter siswa SMA Negeri 02 Sungai Keruh, Faktor pendukung yaitu Guru pendidikan agama bersama-sama para guru-guru yang lain dapat merancang berbagai aktifitas sehari-hari, fasilitas pendidikan, adanya program- program sekolah baik secara akademik dan non akademik,Faktor penghambat yaitu perbedaan Guru terkadang memprioritaskan penyelesaian materi tanpa memperhatikan aspek penanaman nilai-nilai karakter, Masih ada siswa yang sulit untuk diarahkan, Pergaulan siswa yang sulit dikontrol, Kurangnya atau tidak adanya pelatihan guru mengenai penanaman nilai- nilai karakter.

Selanjutnya dapat diajukan beberapa saran yaitu kepala sekolah diharapkan mengupayakan peningkatan pemahaman siswa terhadap pendidikan karakter sehingga anak dapat memiliki karakter yang baik, hal ini dapat dilakukan dengan mendatangkan narasumber dan menyediakan buku-buku yang berkaitan dengan pendidikan karakter. Guru harus meningkatkan terus kualitas pembelajaran di dalam kelas dengan berbagai metode pembelajaran. Hendaknya guru juga memahami karakteristik siswa sehingga dalam pemilihan metode pembelajaran sesuai dengan karakteristik siswa. Siswa lebih baik lagi dalam membudayakan nilai karakter di sekolah dan di luar sekolah. Para siswa harus tetap selalu mematuhi peraturan yang berlaku di sekolah dan dapat meneladani perilaku baik dari para pendidik sehingga diharapkan siswa dapat mengimplementasikan perilaku baik tersebut di sekolah dan di luar sekolah. Sekolah harus berupaya lebih memajukan pendidikan karakter dengan menyediakan sarana prasarana yang belum tersedia dan melakukan evaluasi pendidikan karakter dengan semua tenaga pendidik maupun orang tua. 


\section{Daftar Pustaka}

Andriani,P. (2002). Pendidikan Pancasila. Yogyakarta:UNY press.

Arifin, M. (1978). Hubungan Timbal Balik Pendidikan Agama di Lingkungan Sekolah dan Keluarga. Jakarta: Bulan Bintang Majid.

Ainiyah, N. Jurnal Pembentukan Karakter Melalui Pendidikan Agama Islam. Jawa Tengah: Universitas Negeri Semarang.

Arismantoro. (2008). Character Building. Yogyakarta: Tiara Wacana.

Baroroh, U. R. Jurnal beberapa konsep dasar proses belajar mengajar dan Aplikasinya dalam pembelajaran pendidikan agama Islam. Jawa tengah: universitas sunan kalijaga.

Creswell, John W. (2014). Research Design (pendekatan kualitatif,kuantitatif,dan mixed). Yogyakarta:Pustaka Pelajar.

Daroeso, Bambang. (1986). Dasar-dasar dan Konsep Pendidikan Moral Pancasila. Semarang: Aneka Ilmu.

Djamarah, Syaiful Bahri. (2000). Guru dan Anak Didik dalam Interaksi Edukatif, Jakarta: PT. Rineka Cipta.

Harahap. (2007). Kamus besar bahasa Indonesia. Bandung:Balai Pustaka.

Jalaluddin dan Idi, A. Filsafat Pendidikan (Manusia, Filsafat, dan Pendidikan), Jakarta: Penerbit Gaya Media Pratama Jakarta, 2002.

Langgulung, H. (2000). Beberapa Pemikiran Tentang Pendidikan Islam. Bandung: PT. Al-Ma'rif.

Mulyana, D. (2004). Metodologi Penelitian Kualitatif. Bandung: PT Remaja Rosda Karya.

Megawangi, R. (2004). Pendidikan Karakter. Jakarta: BPMIGAS.

Mulyati E. Jurnal Analisis Model-Model Pendidikan Karakter Untuk Usia Anak-Anak. Remaja. dan Dewasa. UNY.

Padjrin, Padjrin. "Pola Asuh Anak Dalam Perspektif Pendidikan Islam". Jurnal Intelektualita: Keislaman, Sosial dan Sains 5, no. 1 (September 6, 2016): 1 - 14. $\begin{array}{lll}\text { Accessed January 28, } & 2019 .\end{array}$ http://jurnal.radenfatah.ac.id/index.php/intelektualita/article/view/720.

Sjarkawi. (2008). Pembentukan Kepribadian Anak Peran Moral, Intelektual, Emosional, dan Sosial Sebagai Wujud Integritas Membangun Jati Diri. Jakarta: PT Bumi Aksara.

Syah, M. (2013). Psikologi Pendidikan dengan Pendekatan Baru, cet. XVIII, Bandung: PT. Remaja Rosdakarya.

Poerwadarminta. (2011). Kamus Umum Bahasa Indonesia. cet. X. Jakarta: PT. Balai Pustaka.

Susanti, E. Jurnal pendidikan agama berbasis multikultural. Jawa tengah: uin sunan ampel surabaya. 
